\title{
Psychrophilic Full Scale Tubular Digester Operating over Eight Years: Complete Performance Evaluation and Microbiological Population
}

\author{
Jaime Jaimes-Estévez ${ }^{1}$, German Zafra ${ }^{2}{ }^{\mathbb{D}}$, Jaime Martí-Herrero ${ }^{3,4}{ }^{*} \mathbb{D}$, Guillermo Pelaz ${ }^{5}$, Antonio Morán ${ }^{5}$, \\ Alejandra Puentes ${ }^{1}$, Christian Gomez ${ }^{1}$, Liliana del Pilar Castro ${ }^{1}$ and Humberto Escalante Hernández ${ }^{1}$ \\ 1 Centro de Estudios en Investigaciones Ambientales (CEIAM) Research Group, Universidad Industrial de \\ Santander, Bucaramanga, Colombia; jamestev7@gmail.com (J.J.-E.); alepuentesl@saber.uis.edu.co (A.P.); \\ chrisgo@saber.uis.edu.co (C.G.); licasmol@saber.uis.edu.co (L.d.P.C.); escala@uis.edu.co (H.E.H.) \\ 2 Grupo de Investigación en Bioquímica y Microbiología (GIBIM), Universidad Industrial de Santander, \\ Bucaramanga, Colombia; geralzaf@uis.edu.co \\ 3 Biomass to Resources Group, Universidad Regional Amazonica Ikiam, Via Tena-Muyuna, Km.7, \\ Tena, Napo, Ecuador \\ 4 Building Energy and Environment Group, Centre Internacional de Mètodes Numérics en \\ Enginyeria (CIMNE), Terrassa, 08034 Barcelona, Spain \\ 5 Chemical, Environmental and Bioprocess Engineering Group, Universidad de León, Av. Portugal 41, \\ 24009 León, Spain; gpelg@unileon.es (G.P.); amorp@unileon.es (A.M.) \\ * Correspondence: jaime.marti@ikiam.edu.ec
}

check for

updates

Citation: Jaimes-Estévez, J.; Zafra, G.; Martí-Herrero, J.; Pelaz, G.; Morán, A.; Puentes, A.; Gomez, C.; Castro, L.d.P.; Escalante Hernández, H. Psychrophilic Full Scale Tubular Digester Operating over Eight Years: Complete Performance Evaluation and Microbiological Population. Energies 2021, 14, 151. https:// doi.org/10.3390/en14010151

Received: 27 November 2020 Accepted: 25 December 2020 Published: 30 December 2020

Publisher's Note: MDPI stays neutral with regard to jurisdictional clai$\mathrm{ms}$ in published maps and institutional affiliations.

Copyright: (C) 2020 by the authors. Licensee MDPI, Basel, Switzerland. This article is an open access article distributed under the terms and conditions of the Creative Commons Attribution (CC BY) license (https:// creativecommons.org/licenses/by/ $4.0 /)$.

\begin{abstract}
Most biogas plants in the world run under psychrophilic conditions and are operated by small and medium farmers. There is a gap of knowledge on the performance of these systems after several years of operation. The aim of this research is to provide a complete evaluation of a psychrophilic, low-cost, tubular digester operated for eight years. The thermal performance was monitored for 50 days, and parameters such as $\mathrm{pH}$, total volatile fatty acid (tVFA), chemical oxygen demand (COD) and volatile solids (VS) were measured every week for the influent and effluent. The digester operated at a stabilized slurry temperature of around $17.7^{\circ} \mathrm{C}$, with a mean organic load rate (OLR) equal to $0.52 \mathrm{~kg} \mathrm{VS} / \mathrm{m}^{3}$ digester ${ }^{*} \mathrm{~d}$ and an estimated hydraulic retention time (HRT) of 25 days. The VS reduction in the digester was around $77.58 \%$ and the COD reduction was $67 \pm 3 \%$, with a mean value for the effluent of $3.31 \pm 1.20 \mathrm{~g} \mathrm{COD} / \mathrm{Lt}$, while the tVFA decreased by $83.6 \pm 15.5 \%$ and the presence of coliforms decreased $10.5 \%$. A BioMethane potential test (BMP) for the influent and effluent showed that the digester reached a specific methane production of $0.40 \mathrm{Nm}^{3} \mathrm{CH}_{4} / \mathrm{kg}$ VS and a $0.21 \mathrm{Nm}^{3} \mathrm{CH}_{4} / \mathrm{m}^{3}$ digester $\mathrm{d}$ with $63.1 \% \mathrm{CH}_{4}$ in the biogas. These results, together with a microbiological analysis, show stabilized anaerobic digestion and a biogas production that was higher than expected for the psychrophilic range and the short HRT; this may have been due to the presence of an anaerobic digestion microorganism consortium which was extremely well-adapted to psychrophilic conditions over the eight-year study period.
\end{abstract}

Keywords: low cost digester; psychrophilic anaerobic digestion; thermal behavior

\section{Introduction}

In Latin America, the low-cost tubular digester model (also known as the flexible, balloon or plastic model) is the most popular digester for biogas and digestate production from animal waste [1]. The most common livestock wastes used are cattle and pig manures $[2,3]$. Low cost digesters are characterized by the absence of active mixing devices and/or active heating systems [4]. The controlled use of biodigesters is a sustainable technology for the treatment of animal manure because it produces (i) energy: the biogas produced is often used as fuel for cooking, heating water, and generating electricity for on-site use; (ii) Agricultural benefit: the agronomic use of the effluent from anaerobic 
digestion, due to the presence of primary nutrients (nitrogen, phosphorous, potassium), is used as a soil amendment to improve plant growth [5,6]; (iii) Environmental quality: organic matter in waste manure is reduced and manure is stabilized (permanent odor and pathogen content reduction); and (iv) Social benefit: digesters improve health (reduction of exposure to wood smoke and volatile organic compounds) and quality of life, especially for women and children (who are able to spend significantly less time cooking) in rural zones [7]. Most of these benefits translate directly to energy and fertilizer cost savings for families living in rural areas in Latin America (on average, savings of USD \$600/year for propane and around USD \$50/year by using digestate as fertilizer) [8,9].

The anaerobic digestion (AD) process in low cost digesters is strongly influenced by local conditions such as solar radiation and temperature. For example, Castro et al. [5] reported a specific biogas production of $0.15 \mathrm{~m}^{3}$ biogas $/ \mathrm{kg}$ VS for a $9.5 \mathrm{~m}^{3}\left(7.1 \mathrm{~m}^{3}\right.$ operational volume) low cost tubular digester under mesophilic conditions $\left(25 \pm 2{ }^{\circ} \mathrm{C}\right)$. In contrast, a tubular reactor with similar characteristics (volume and amount fed) in Peru at 2800 m.a.s.1. (16-20 ${ }^{\circ} \mathrm{C}$ ) reached a specific biogas yield of $0.10 \mathrm{~m}^{3}{ }_{\text {biogas }} / \mathrm{kg}$ VS [10]. Therefore, biodigesters operated under psychrophilic conditions may present limitations due to the facts that: (i) microbial activity is slowed because the optimum growth temperature of bacteria and archaea is $37^{\circ} \mathrm{C}$; (ii) the removal of organic matter decreases, as does the concentration of methane in the biogas, and a fraction of this biogas is solubilized in the digestate; and (iii) in view of the above, the digestate contains organic matter that is converted to ammonia $\left(\mathrm{NH}_{3}\right)$ and methane $\left(\mathrm{CH}_{4}\right)$ during storage and soil usage [11]. Thus, this can be translated into a loss of energy efficiency and a larger environmental impact due to the aforementioned gaseous emissions [12]. Hence, the search of new strategies that can solve these problems is still in progress.

In order to improve biogas yield under psychrophilic operation conditions, the increase of HRT could be a favorable strategy, but it implies a larger biodigester size. A diminution of around $5{ }^{\circ} \mathrm{C}$ in operation temperature requires an increase in HRT from 30 to 50 days in order to maintain a similar biogas production and substrate volume [13]. Another alternative to improve biodigester temperature conditions is the implementation of a passive solar heating design (solar radiation gain, insulation and greenhouse) [14] The greenhouse and tank insulation effect allow for the absorption and preservation of heat, which reduce the heat losses from the digester to the environment and to the ground, respectively [1,2]. Additionally, biogas yield can be enhanced with microorganisms which are adapted to low temperatures $\left(<20^{\circ} \mathrm{C}\right)$. According to Feller [15], only microorganisms adapted to psychrophilic conditions can deal with the limitations that occur with temperatures below $20{ }^{\circ} \mathrm{C}$. These adapted microorganisms experience good physiological and ecological conditions in cold environments due to the unique characteristics of their membrane proteins, lipids, and genetic responses to thermal changes. In this sense, psychrotolerant microorganisms make AD possible in cold regions [16]. The AD microbiome comprises several distinct microbial trophic groups from the two evolutionarily distinct domains of bacteria and archaea. High throughput sequencing technology in AD microbiology makes it possible to determine the extensive and complex interactions of microbial communities within their environments and hosts. This procedure has shown that the main microorganism families present in stabilized sludge that proliferate in psychrophilic conditions belong to the families Pseudomonadaceae, Methylophilaceae, Sphingobacteriaceae, Coriobacteriaceae; among others [17].

Latin America presents a diversity of geographical and meteorological conditions which lead to a wide range of temperatures, from psychrophilic $\left(<20^{\circ} \mathrm{C}\right)$ to mesophilic $\left(20-45^{\circ} \mathrm{C}\right)$. Biodigesters that operate in tropical and subtropical regions work in mesophilic conditions, which enables the use of a relatively small digester size, high biogas production and good quality sludge [5]. Mesophilic biodigesters operate mainly with cattle manure as a substrate, obtaining biogas yields ranging from $0.15 \mathrm{~m}^{3}{ }_{\text {biogas }} / \mathrm{kgVS}$ to $0.4 \mathrm{~m}^{3}{ }_{\text {biogas }} / \mathrm{kgVS}$, with an average methane quality of $62.6 \%[5,18]$. In those regions, household digesters have been shown to generate the biogas required to satisfy user requirements [18]. 
Also, there are biodigesters installed at more than $3800 \mathrm{~m}$ above sea level [19], and in cold regions [6]. Due to the environmental conditions (mainly temperature), anaerobic digestion performance is affected. Under such conditions, the biogas digester yields ranged from 0.03 to $0.44 \mathrm{~m}^{3}$ biogas $/ \mathrm{KgVS} \mathrm{d}$ with a reduced quality $(60 \%$ and $49.6 \%$ of $\mathrm{CH}_{4}$, respectively) [10,19]. Garfi el al. [20] reported that the biogas production in high altitude regions covers just around $60 \%$ of fuel needs for cooking; this could be improved by enhancing the digester design and using biofilm carriers [1], despite the fact that the use of digester effluent, known as bioslurry or biol, is, in many cases, more important to small- and medium-scale farmers than biogas [19]. Moreover, after a long period of biodigester operation, some operative problems such as clogging in the inputs and outputs, stagnation in the digester, shortcomings in feeding, changes in diet and solid accumulation may appear [21,22]. Therefore, it is necessary to accomplish a diagnosis of household digester performance after long periods of operation. On the other hand, understanding the microbial communities (through taxonomic analyses) in household digesters in cold climates could help to fundamentally improve the AD process and encourage its widespread application [23]. Unfortunately, most previous investigations have only focused on biogas yield and general monitoring during digester start up, and have not assessed the anaerobic digestion performance after several years of operation. The present research attempts to fill this gap by assessing the performance of psychrophilic rural digesters after several years of operation in continuous mode by examining the following: (i) thermal performance, (ii) bioprocess stability, (iii) microbiological analysis, and (iv) digestate quality. In this study, the performance of a medium-sized biogas plant in a rural area, which had been operating continuously for eight years under psychrophilic conditions, was diagnosed.

\section{Materials and Methods}

\subsection{Site Description}

Research was conducted at a Colombian pig farm at an altitude of $2963 \mathrm{~m}$ above sea level (m.a.s.l.) and a latitude of $\mathrm{N}^{\circ} 27^{\prime} 45.0^{\prime \prime} \mathrm{W} 72^{\circ} 24^{\prime} 43.0^{\prime \prime}$. According to the Colombian Institute of Hydrology, Meteorology and Environmental Studies (IDEAM), the environmental temperature varied throughout the year between $12 \pm 3^{\circ} \mathrm{C}$ [24]. This farm had 456 pigs fed with cheese whey and water. The digester was feed with the excrete produced by 255 animals. The farm is $16.5 \mathrm{~km}$ from the Cocuy National Natural Park. The digester had been operated for the last 8 years, and the monitoring period was 50 days.

\subsection{Description of Rural Biogas Plant}

For the management of the pig manure, the farm used a double layer tubular polyethylene (caliber 8 and UV protection, common greenhouse plastic) digester for over 8 years. The digester dimensions were $30 \mathrm{~m}$ in length, $2.5 \mathrm{~m}$ in diameter and $147.3 \mathrm{~m}^{3}$ total volume (operational volume is $103.1 \mathrm{~m}^{3}$ ). The digester was covered by a polyethylene greenhouse that provided environmental protection. The daily excrete was composed of a pig manure and urine blend which represented $0.60 \mathrm{~m}^{3}$ of total fed. This digester was fed daily with $4.16 \mathrm{~m}^{3} / \mathrm{d}$ of a mixture of excrete and free-range wash water in a 1:6 ratio. The digester HRT was around 25 days. The biogas produced in the biodigester was used to heat an enclosure containing about 160 piglets. The installed biodigester installed did not have a biogas measurement system. 


\subsection{Monitoring Temperature in the Biodigester}

To carry out the temperature profiles analysis, four datalogger sensors were installed with the objective of monitoring temperature (ambient, interior of the greenhouse, slurry and ground) and luminosity. The datalogger location and specifications are reported in Figure 1 and Table 1.

The sensors were set up to record the temperature every hour. The description of the location and method of installation of the sensors was as follows: (a) Tamt (sensor 1) monitored the ambient temperature around the greenhouse. (b) Tga (sensor 2) was the device by which variations in the temperature of the air inside the greenhouse were recorded; this device was oriented south-north to also monitor the solar luminosity which affected the performance of digester. (c) Ts (sensor 3) recorded variations in the slurry temperature data; this sensor was located one meter inside the biodigester bag. (d) Tgr (sensor 4) monitored soil temperature; this device was located one meter underground.

Meteorological data included solar radiation and ambient temperature, which were measured and collected every hour for 50 days.

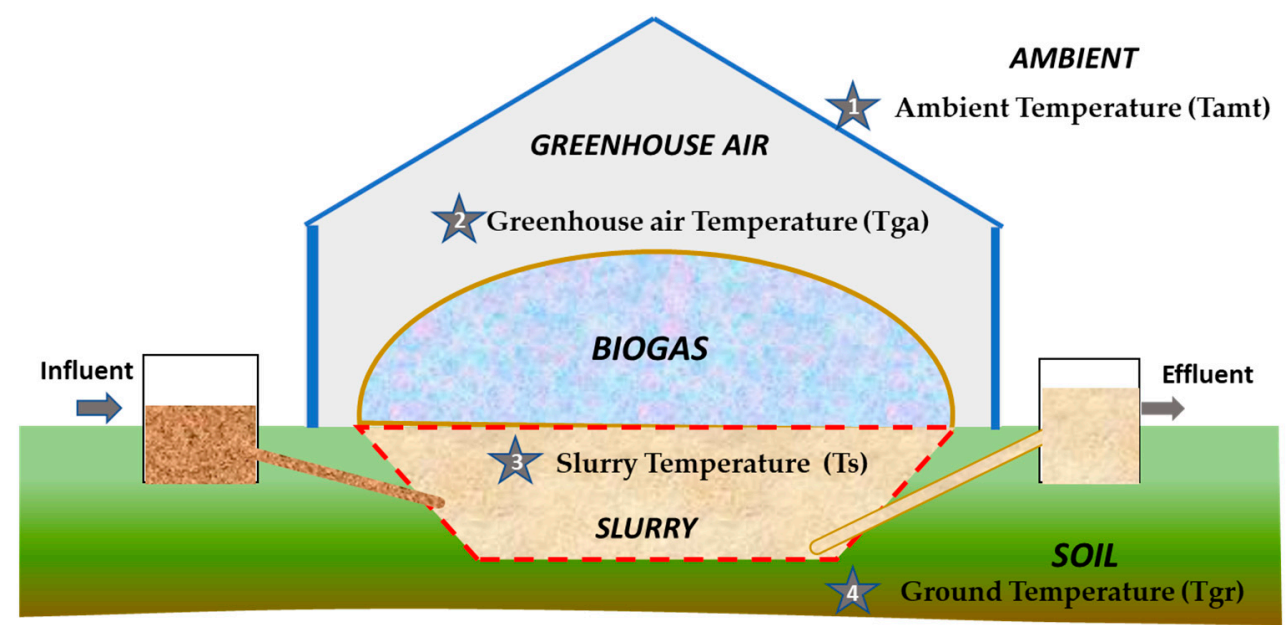

Figure 1. Digester scheme and location of temperature sensors.

Table 1. Location and characteristics of temperature sensors.

\begin{tabular}{|c|c|c|c|c|c|}
\hline Name & Data & Location & Equipment & Resolution & Accuracy \\
\hline $\begin{array}{l}\text { Tamt } \\
\text { (sensor 1) }\end{array}$ & $\begin{array}{l}\text { ambient } \\
\text { temperature }\end{array}$ & $\begin{array}{l}\text { around the } \\
\text { greenhouse }\end{array}$ & $\begin{array}{l}\text { HOBO UA-001-08 Pendant }{ }^{\circledR} \\
\text { Waterproof Data Logger }\end{array}$ & $0.14^{\circ}$ & \\
\hline $\begin{array}{l}\text { Tga } \\
\text { (sensor 2) }\end{array}$ & $\begin{array}{l}\text { air } \\
\text { temperature/solar } \\
\text { luminosity }\end{array}$ & inside greenhouse & $\begin{array}{l}\text { HOBO UA-002-64 Pendant }{ }^{\circledR} \\
\text { Temperature/Light } 64 \text { K Data } \\
\text { Logger }\end{array}$ & $\begin{array}{l}0.14^{\circ} / \text { Designed for } \\
\text { relative light levels }\end{array}$ & $\begin{array}{c} \pm 0.53{ }^{\circ} \mathrm{C} \text { from } 0{ }^{\circ} \mathrm{C} \\
\text { to } 50{ }^{\circ} \mathrm{C}\end{array}$ \\
\hline Ts (sensor 3) & Slurry temperature & $\begin{array}{l}\text { one meter into the } \\
\text { biodigester bag }\end{array}$ & $\begin{array}{l}\text { HOBO UA-001-08 Pendant } \\
\text { Waterproof Data Logger }\end{array}$ & $0.14^{\circ}$ & \\
\hline $\begin{array}{l}\text { Tgr } \\
\text { (sensor 4) }\end{array}$ & Soil temperature & $\begin{array}{l}\text { one meter } \\
\text { underground }\end{array}$ & $\begin{array}{l}\text { HOBO UA-001-08 Pendant } \\
\text { Waterproof Data Logger }\end{array}$ & $0.14^{\circ}$ & \\
\hline
\end{tabular}

\subsection{Diagnosis of Anaerobic Digestion in the Pig Farm Digester}

A diagnosis (performance and stability) of the pig biogas plant was performed by studying the biochemical and microbiological behavior. The biodigester was monitored for 50 days by taking a weekly sample of the influent and effluent. Regular operational conditions remained unaltered. The samples were stored and refrigerated before analysis. All experiments were performed in triplicate. The $\mathrm{CH}_{4}$ biogas content was determined by gas chromatography using a TCD detector on a GC-Agilent $7890^{\mathrm{a}}$ brand chromatograph, using Argon as a drag gas and a 1010 plot Carboxen capillary column (length $30 \mathrm{~m}$, internal diameter $0.32 \mathrm{~mm}, 25 \mu \mathrm{m}$ stationary phase internal layer). The $\mathrm{CO}_{2}$ content was determined by balance (assuming biogas to be a mixture of $\mathrm{CH}_{4}$ and $\mathrm{CO}_{2}$ ). 


\subsubsection{Biochemical Assays}

The organic matter content was measured in terms of volatile solids (VS) and total chemical oxygen demand (COD), according to standard procedures $2540 \mathrm{G}$ and $5220 \mathrm{D}$, respectively [25]. Measuring the digester $\mathrm{pH}$, total carbonate alkalinity (TA) and total volatile fatty acids (tVFA) concentrations indicated the process stability. $\mathrm{pH}$ was measured with a Metrohm $691 \mathrm{pH}$ Meter. TA and tVFA were measured by $\mathrm{pH}$ titration to 4.3, according to the method described by Purser et al. [26]. Individual VFAs (C2-C6) were measured using a 7820A gas chromatograph (Agilent, Santa Clara, CA, USA) equipped with a flame ionization detector and an Innowax column (Agilent, USA).

A biomethane potential (BMP) assay was developed following the methodology proposed by Holliger et al. (2016), but under psychrophilic temperature conditions $\left(15 \pm 2{ }^{\circ} \mathrm{C}\right)$. An experimental setup was constructed using $120 \mathrm{~mL}$ glass bottles with a $50 \%$ working volume. Digestate from the pig farm digester was used as the inoculum, keeping the digester working temperature. The substrate-to-inoculum ratio was 1:1 (VS basis). To measure endogenous methane production, a blank assay (inoculum without substrate) was included. Additionally, a positive control test with crystalline cellulose (97\%) was conducted. As BMP, the residual biomethane potential of the digestate was measured in batch experiments $\left(60 \mathrm{~mL}\right.$ of inoculum working volume of at $\left.15 \pm 2{ }^{\circ} \mathrm{C}\right)$. To guarantee an anaerobic atmosphere, the bottles were flushed with a $80 / 20 \% \mathrm{~N}_{2} / \mathrm{CO}_{2}$ mixture and sealed with aluminum caps and butyl rubber stoppers. Methane production was quantified daily by volume displacement of a sodium hydroxide solution $(2 \mathrm{~N})$, and normalized to standard conditions $\left(0{ }^{\circ} \mathrm{C}\right.$ and 1 atmosphere). The BMP and residual biomethane potential tests were concluded when the volume of methane accumulated increased by less than $1 \%$ for three consecutive days.

\subsubsection{Microbiological Analysis of Pig Farm Digester}

Microbiological behavior was evaluated as a function of:

(i) Specific Methane Activity (SMA): the inoculum (digestate from pig farm biodigester) specific methanogenic activity at $15 \pm 2{ }^{\circ} \mathrm{C}$ (local conditions) and $35 \pm 2{ }^{\circ} \mathrm{C}$ (optimal condition). A SMA test was performed, in accordance with Astals et al. [27]. SMA experiments were performed in triplicate in $120 \mathrm{~mL}$ serum bottles, with a working volume of $60 \mathrm{~mL}$. Sodium acetate was used as model substrate. A substrate-free blank was included to measure endogenous methane production from the inoculum. The methane produced during the SMA assay was quantified by measuring the volumetric displacement of an alkaline solution $(2 \mathrm{~N})$. The measured methane was normalized and expressed in terms of COD equivalents.

(ii) The taxonomic classification of bacterial and archaeal communities: first, genomic DNA was extracted from the digester influent and effluent using the PowerSoil ${ }^{\circledR}$ DNA Isolation Kit (MoBio Laboratories Inc., Carlsbad, CA, USA), according to the producer's recommendations. PCR reactions were carried out in an Eppendorf Mastercycler and PCR samples were checked for product size on a 1\% agarose gel. Then, the entire DNA extract was used for high throughput sequencing of 16S rRNA genebased massive libraries for eubacterial and archaeal communities. The primer set used for the eubacterial population analysis was 27Fmod (5'-AGRGTTTGATCMTGGCTCAG$3^{\prime}$ )/519R modBio (5'-GTNTTACNGCGGCKGCTG-3') [28]. For the archaeal population analysis, the primer set was Arch 349F (5'-GYGCASCAGKCGMGAAW-3')/Arch 806R (5'GGACTACVSGGGTATCTAAT-3') [29]. The obtained DNA reads were compiled in FASTq files for further bioinformatic processing [30]. Finally, operational taxonomic units were taxonomically classified using the Ribosomal Database Project, available at https://rdp.cme.msu.edu/.

(iii) The quantitative analysis of Bacteria and Archaea: bacteria an archaea populations were analyzed by means of quantitative-PCR reaction (qPCR) using PowerUp SYBR Green Master Mix (Applied Biosystems) in a StepOne plus Real Time PCR System (Applied 
Biosstems) [31]. The primer sets were $341 \mathrm{~F}$ and $518 \mathrm{R}$ for bacteria and mcrF and mcrR for archaea.

(iv) The pathogen content: fecal and total coliform in the influent and effluent were determined using a serial dilution, deep-plating technique in chromogenic culture media.

The global methodology of this study is presented in Figure 2.

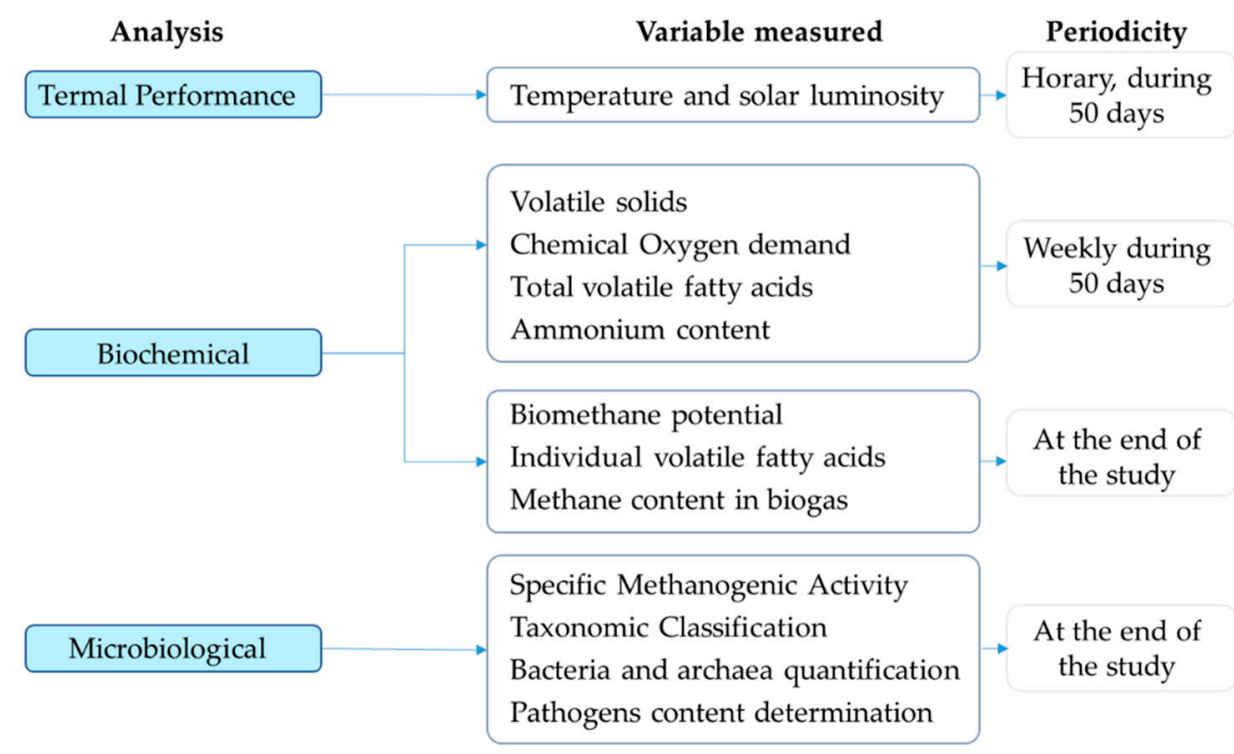

Figure 2. Methodology summary: analysis, variables measured and periodicity during biodigester monitoring.

\section{Results and Discussion}

\subsection{Thermal Behavior of the Digester}

Figure 3 a shows the typical dynamical daily performance of the temperatures in the digester, while Figure $3 b, c$ show the thermal performance for 5 days (as a tendency example during the monitoring time), and 50 consecutive days, respectively. The ambient temperature (Tamt) shows a typical daily bell shape that the green house temperature follows with higher amplitude. The maximum ambient temperature was $27.9{ }^{\circ} \mathrm{C}$ and the minimum was $9.5^{\circ} \mathrm{C}$, while the greenhouse temperature ranged between $35.5^{\circ} \mathrm{C}$ and $6.8^{\circ} \mathrm{C}$. These data show that the greenhouse warmed up during the day but cooled during the night due to radiative cooling. In other studies, such as those by Perrigault et al. [14] and Martí-Herrero et al. [32], the greenhouses were built with adobe walls and were airtight, thereby achieving thermal inertia and keeping the greenhouse warm during the night. However, in the pig farm digester, the greenhouse was made only of plastic, without thermal inertia and allowing more air exchange, producing lower internal temperatures than those found outside. This night cooling effect can be avoided through the selection of proper plastic; or adding thermal inertia and airtight to the walls of the greenhouse.

The slurry temperature (Ts) showed a flat performance with a mean temperature $17.7^{\circ} \mathrm{C}$, independent of daily variations (Figure $3 \mathrm{~b}$ ). The mean ground temperature (Tgr) was $16.3^{\circ} \mathrm{C}$, which was very close to the mean ambient temperature of $16.6^{\circ} \mathrm{C}$ (Figure $3 \mathrm{c}$ ). This means that the Ts was only $1.1^{\circ} \mathrm{C}$ over the ambient temperature, while an improved solar heating design in the digester led to increments of Ts over $10^{\circ} \mathrm{C}$ with respect to ambient temperatures [1]. Martí-Herrero et al. [16] showed the performance of a tubular digester under similar weather conditions, where the slurry temperature followed the values of the maximum ambient temperature using just black plastic and $1 \mathrm{~cm}$ insulation in the trench, without a greenhouse. This means that a greenhouse without insulation or black plastic is not enough for the solar heating of tubular digesters. 

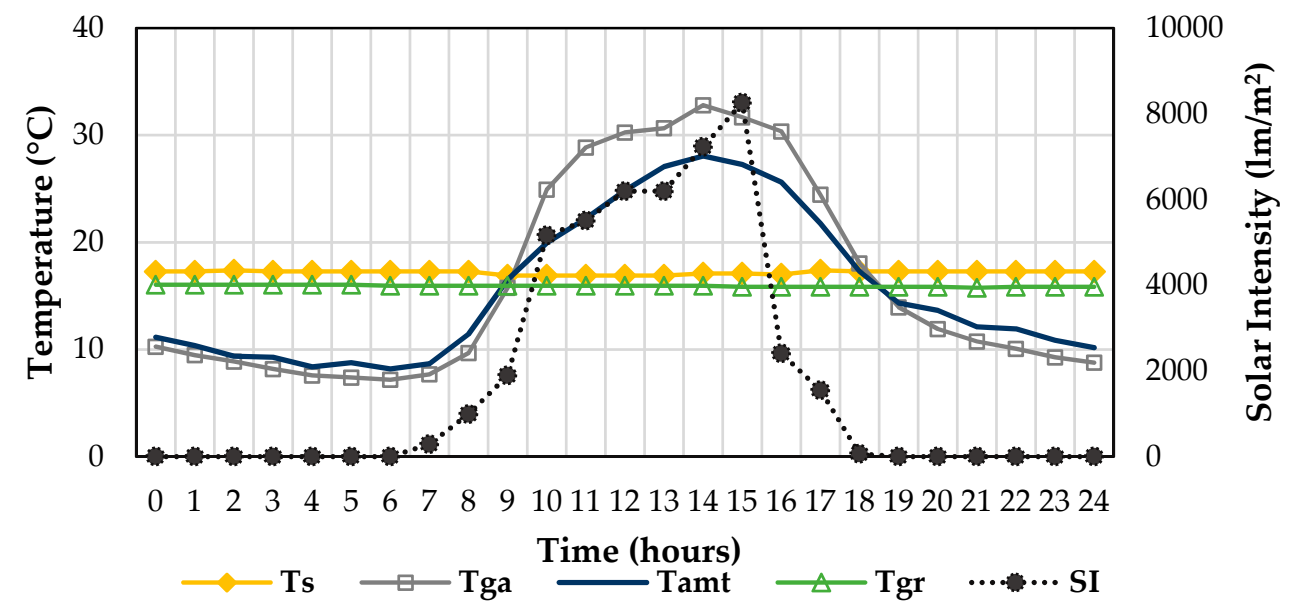

(a)

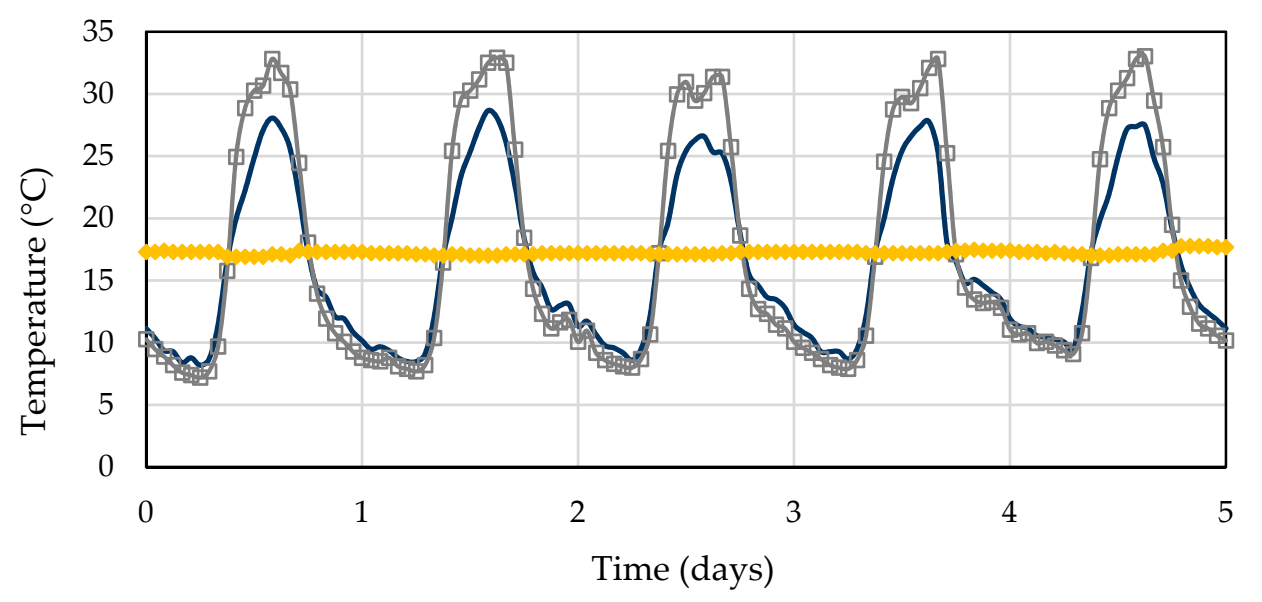

$\longrightarrow$ Tamt $\longrightarrow$ Tga $\multimap$ Ts

(b)

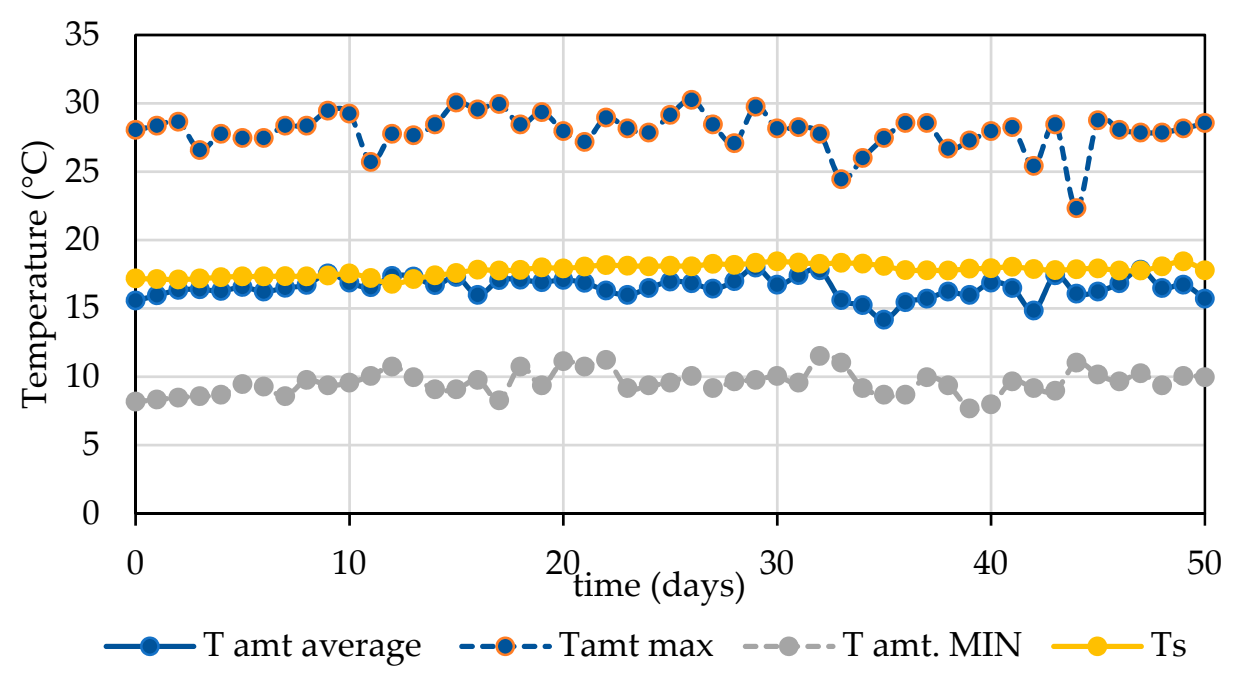

(c)

Figure 3. Thermal behavior of the digester. (a) Profiles of Ts, Tga, Tamt, Tgr, Tgh, Ts with solar luminosity for a day. (b) Profiles of Tamt, Tga, Ts for 5 days, (c) Behavior for 50 days of Tamt, Tamt max, Tamt min, Ts average. 


\subsection{Changes in Control Parameters in Pig Farm Digester}

Plug flow digesters regularly operate with OLR from $0.5 \mathrm{~kg} \mathrm{VS} / \mathrm{m}^{3}{ }_{\text {digester }}{ }^{*} \mathrm{~d}$ to $1.0 \mathrm{~kg} \mathrm{VS} / \mathrm{m}^{3}{ }_{\text {digester }}{ }^{*} \mathrm{~d}[2]$. During monitoring, the OLR ranged from $0.34 \mathrm{~kg} \mathrm{VS} / \mathrm{m}^{3}$ digester ${ }^{*} \mathrm{~d}$ to $0.76 \mathrm{~kg} \mathrm{VS} / \mathrm{m}^{3}$ digester ${ }^{*} \mathrm{~d}$ (average HRT $=25 \mathrm{~d}$ for a slurry temperature of $17.7^{\circ} \mathrm{C}$ ). This was because the manure was diluted during the cleaning of the pig shed with no wash water volume regulation. To achieve an adequate functioning of the digester, a previous dilution of the substrates was required which avoided clogging in the load and scum formation on its surface, and ensured continuous flow operation. The operational parameters of the digester are summarized in Table 2. Previous studies carried out with porcine manure reported that a 1:7 dilution favors the hydrolytic and methanogenic activities and the biomethane potential of the process [33]. Regarding the organic matter, the average VS of the influent decreased from $12.74 \pm 3.52 \mathrm{~g} \mathrm{VS} / \mathrm{kg}$ to a mean value of $2.86 \mathrm{~g} \pm 1.20 \mathrm{~g} \mathrm{VS} / \mathrm{kg}$, which means an organic matter removal around $77.58 \%$. In comparison with a tubular system fed with swine manure and operating at an average temperature range of $25-30{ }^{\circ} \mathrm{C}$, VS removal was $83 \%$ [18]. This comparation allowed us to infer that temperature affects the removal of volatile solids. A similar conclusion was reached in recent research focused on $\mathrm{AD}$ in cold regions [34].

The organic matter content (g COD/L) variation with respect to OLR is presented in Figure 4. The influent and effluent average COD were $9.94 \pm 3.25 \mathrm{~g} \mathrm{COD} / \mathrm{L}$ and $3.31 \pm 1.20 \mathrm{~g}$ COD/L, respectively. In the AD process, an increase in OLR caused a decrease in COD removal efficiency. In this study, the results showed a diminution in COD from $70 \%$ to $62.5 \%$ for OLR of $0.34 \mathrm{~kg} \mathrm{VS} / \mathrm{m}^{3} \mathrm{~d}$ and $0.76 \mathrm{~kg} \mathrm{VS} / \mathrm{m}^{3} \mathrm{~d}$, respectively. On average, the COD bioconversion achieved in the present study was $67 \pm 3 \%$. Previous studies have achieved higher organic matter removal in domestics plug-flow digester systems treating pig manure. Digesters operating at $23 \pm 2{ }^{\circ} \mathrm{C}, 24.5 \pm 1.5{ }^{\circ} \mathrm{C}$ and $26 \pm 1.5{ }^{\circ} \mathrm{C}$ reported COD removal rates of around 88.5\% [35], 78.5\% [36] and 92\% [18]. So, digesters working at psychrophilic temperature over $20^{\circ} \mathrm{C}$ have been shown to achieve significant organic matter removal (around 28\% more).

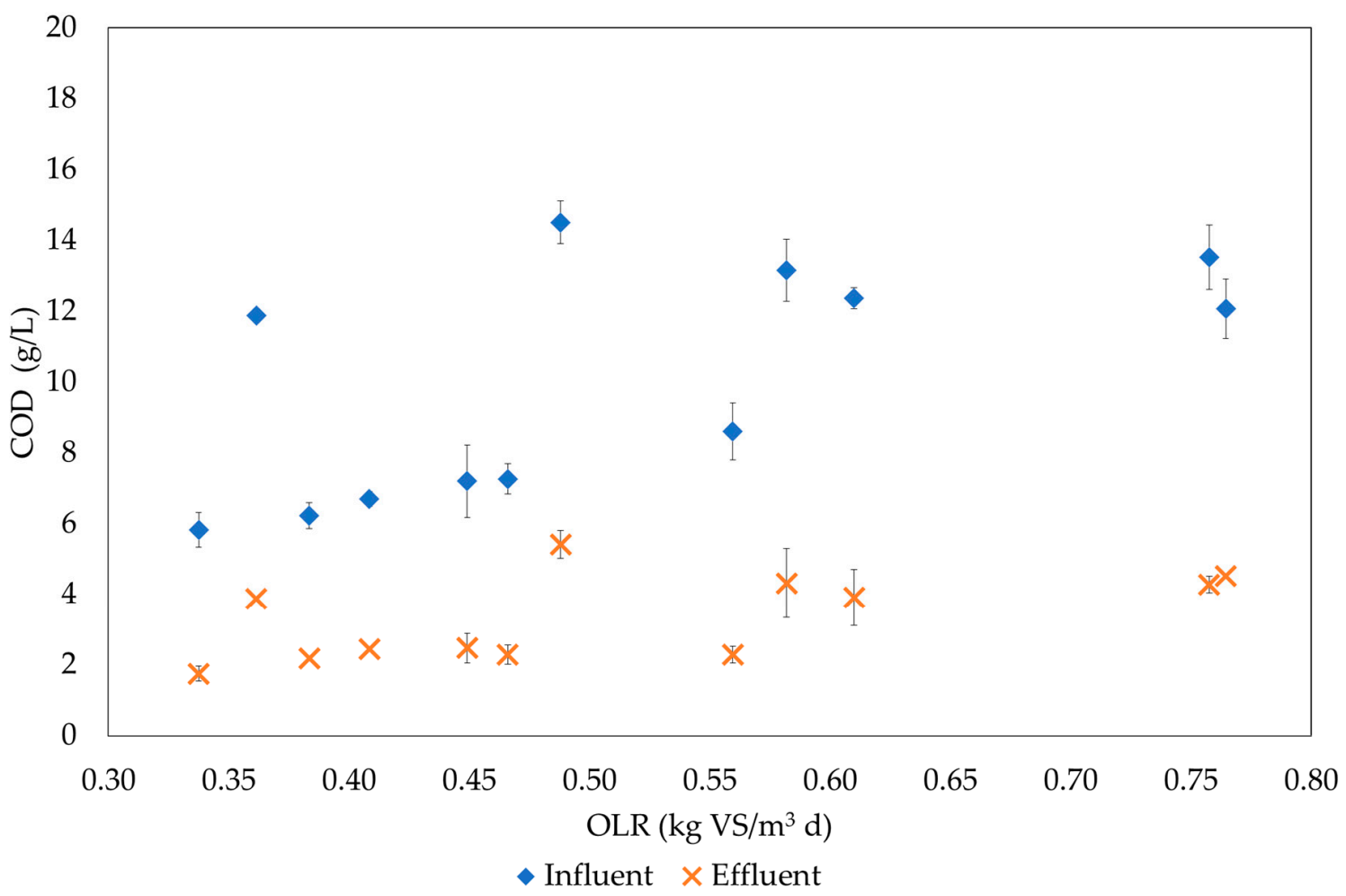

Figure 4. Chemical oxygen demand concentration for influent (blue rhombuses) and effluent (orange cruxes) during OLR changes. 
Effluent tVFA concentration represents the easily biodegradable organic matter that was not metabolized in anaerobic processed. Figure 5 shows that the effluent tVFA concentrations were around $0.30 \pm 0.08 \mathrm{~g}$ COD VFA/L. On average, the tVFA decrease was around $2.6 \pm 1.4 \mathrm{~g} \mathrm{COD}_{\mathrm{VFA}} / \mathrm{L}$, which represents a bioconversion of $83.6 \pm 15.5 \%$. A rural biodigester with one year of continuous operation at $34{ }^{\circ} \mathrm{C}$ showed $63 \%$ of tVFA bioconversion [5]. Thus, with a longer operational period, it is possible to achieved higher conversion rates of soluble organic matter, even under psychrophilic conditions. These results demonstrated that the pig farm biodigester was operating efficiently, even after 8 years of continuous operation without maintenance.

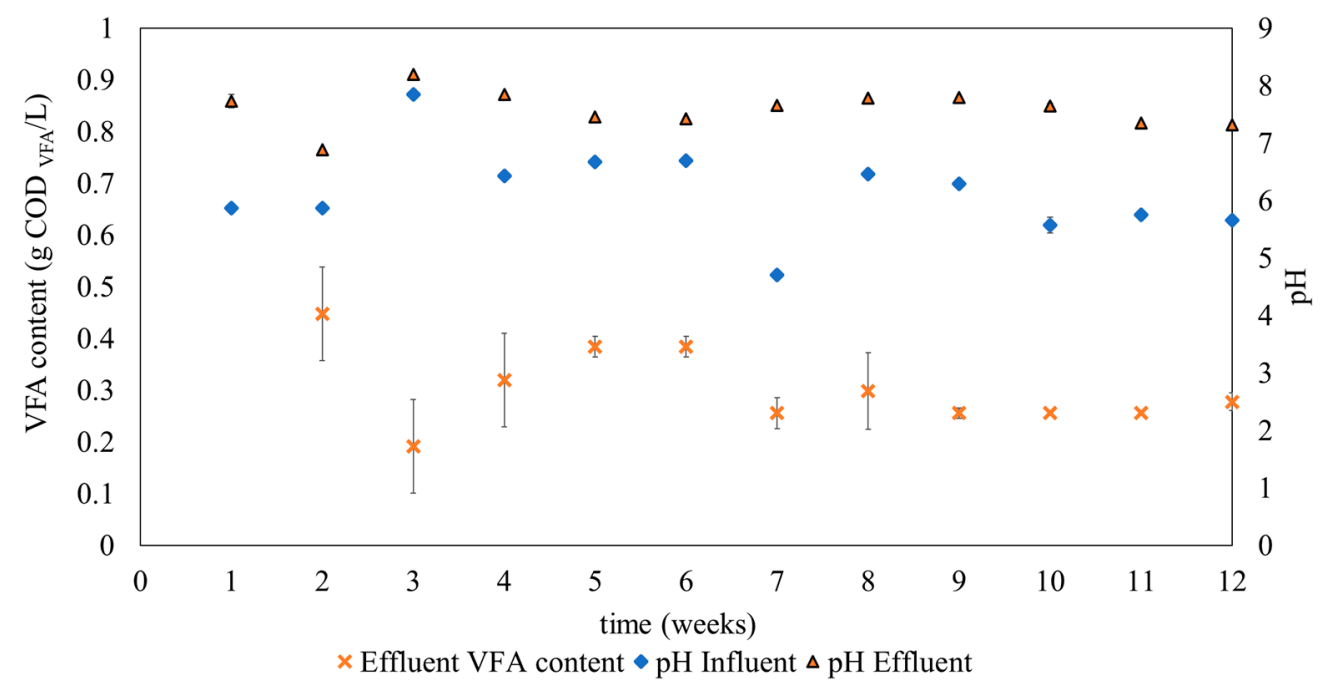

Figure 5. Effluent total volatile fatty acids concentration (orange cruxes) and influent and effluent $\mathrm{pH}$ (blue rhombus and orange triangles, respectively) during monitoring.

A diminution in temperature could affect the stability of the fermenting microorganisms. This change in stability may cause $\mathrm{pH}$ changes and decrease methane yield [37]. In the present study, the $\mathrm{pH}$ value for both the influent and effluent was $6.1 \pm 0.8$ and $7.6 \pm 0.3$ at psychrophilic temperature. The $\mathrm{pH}$ range for a healthy and continuous $\mathrm{AD}$ process is 6.8-8.2 [11]. The FOS/TAC ratio ranged between $0.72 \pm 0.2-0.17 \pm 0.1 \mathrm{mg}$ of acetic acid $/ \mathrm{mg}$ of $\mathrm{CaCO}_{3}$ for the affluent and effluent, respectively. This demonstrates the high buffer capacity of pig manure. FOS/TAC values below $0.8 \mathrm{mg}$ acetic acid/mg $\mathrm{CaCO}_{3}$ are adequate for process stability [5]. This confirmed that the pig farm digester was operating properly without inhibition risk. As such, variations in OLR and temperature did not affect the anaerobic processes.

Individual VFA of the affluent and effluent (Figure 6) showed that acetic acid is most prevalent in the affluent ( $71 \%$ in relation to the other acids), indicating stable anaerobic fermentation. Butyric acid showed the best conversion (98\%) compared to the other acids, and was the second most prevalent. These results can be compared with those in previous studies, where it has been shown that butyric acid fermentation plays a significant role during low temperature anaerobic degradation [38]. 


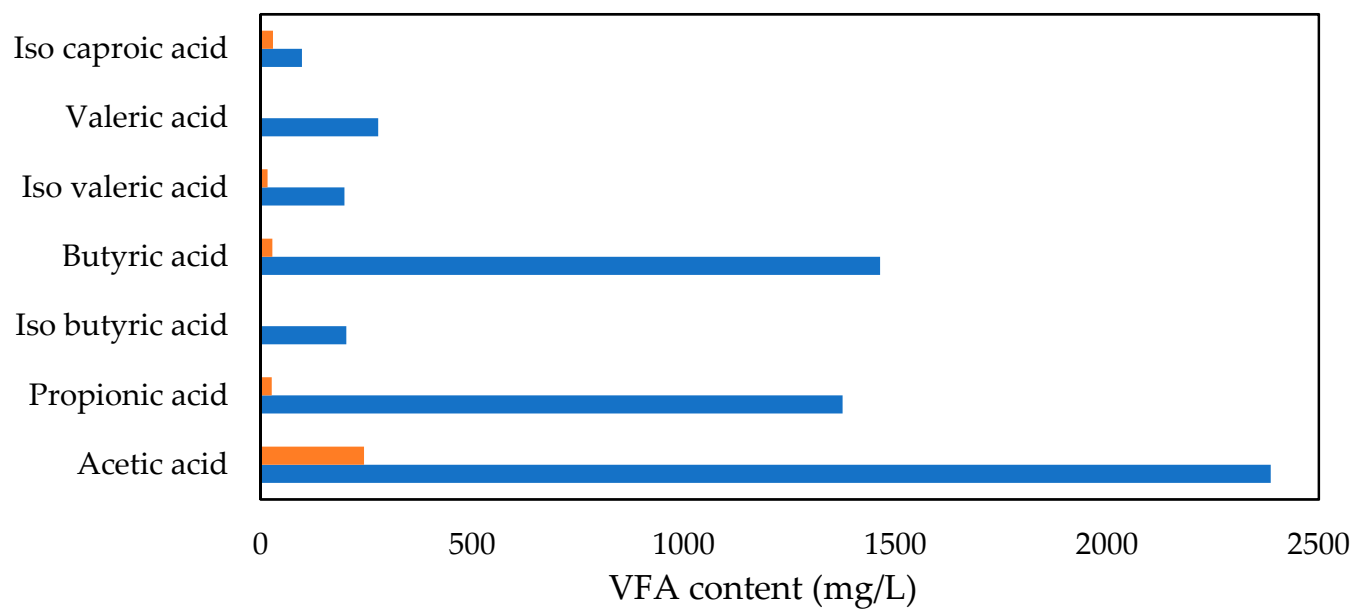

Figure 6. Individual VFAs (C2-C6) concentration in fed (affluent -blue bars-) and digestate (effluent -orange bars-).

According to the literature, a healthy digester has ratios of $\mathrm{Pr} / \mathrm{Ac}$ below 1.4 with an acetic acid concentration under $800 \mathrm{mg} / \mathrm{L}$. This value indicates that there is a propionate accumulation which represents a reduction in methane content due to hydrogenogenic bacteria inhibition. [39]. Although the VFA content varies along the digester [40], the outlet $\mathrm{Pr} / \mathrm{Ac}$ ratio was 0.11 (acetic acid concentration of $244 \mathrm{mg} / \mathrm{L}$ ). Up to now, there are no reports of individual volatile fatty acid values for low cost tubular digesters. As stated above, it can be affirmed that after a significant period of adaptation (8 years), the low-cost digester adapts to the temperature conditions and operates satisfactorily.

Ammonium is attributed to the mineralization of organic matter and is an indicator of bioprocess stability. The changes of $\mathrm{NH}_{4}-\mathrm{N}$ during anaerobic fermentation in the low cost tubular digester are shown in Figure 7.

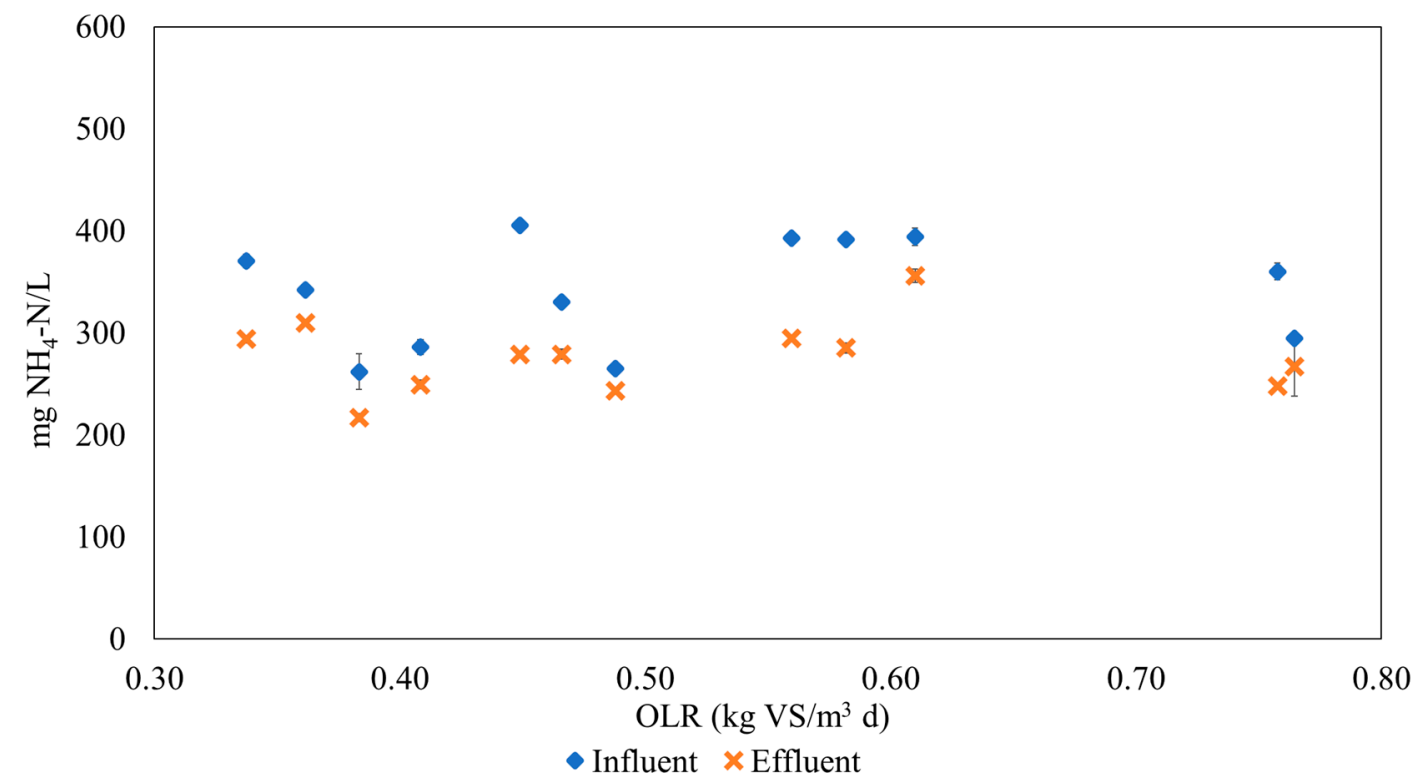

Figure 7. Ammonium changes in affluent (blue rhombus) and effluent (orange cruxes).

Operating under the local environmental conditions (Psychrophilic AD), there were smaller variation of ammonium. Previous studies revealed an ammonium increase under mesophilic and thermophilic conditions [41]. In this study, average $\mathrm{NH}_{4}-\mathrm{N}$ decreased from $341.1 \pm 52$ to $276.8 \pm 36 \mathrm{mg} / \mathrm{L}$. The ammonium concentration did not exceed $355.7 \mathrm{mg} / \mathrm{L}$ during the whole $\mathrm{AD}$ process at $17^{\circ} \mathrm{C}$. It is well known that high concentrations of ammonia $(\geq 3000 \mathrm{mg} / \mathrm{L}$ ) are toxic to microorganisms [42]. The toxicity of ammonia may have been 
insignificant in this study. This is because the low-cost tubular digester had low organic loads, and operated at a low temperature, so the accumulation of inhibitors/toxins was likely negligible. Our results agree with those of Massé et al. [43] and Wei and Guo [44], who stated that at low temperatures, ammonium concentrations do not cause failures in digesters.

\section{Process Efficiency and Biogas Quality}

Figure 8 presents the biomethane potential kinetic for influent (BMP) and effluent (residual methane potential). The BMP test at $15^{\circ} \mathrm{C}$ lasted 40 days, i.e., until methane production was less than $1 \%$. The BMP for the influent at a temperature of $15^{\circ} \mathrm{C}$ was $0.49 \pm 0.053 \mathrm{Nm}^{3} \mathrm{CH}_{4} / \mathrm{kg}$ VS. Significant differences were not found between the BMP values obtained with a $95 \%$ confidence level $(p$-value $=0.2861)$. The methane potential of the affluent at $15{ }^{\circ} \mathrm{C}$ using the local adapted microorganism consortia was higher than other data reported at $36.5^{\circ} \mathrm{C}$ by Kafle and Chen [45], who observed a maximum of $0.33 \mathrm{Nm}^{3} \mathrm{CH}_{4} / \mathrm{kg}$ VS. The residual methane potential at $15{ }^{\circ} \mathrm{C}$ of the effluent was $0.09 \pm 0.005 \mathrm{Nm}^{3} \mathrm{CH}_{4} / \mathrm{kg}$ VS. Residual methane potential values did not present significant differences ( $p$-value $=0.17$ with $95 \%$ of confidence level). The biogas composition generated by the biodigester showed a favorable value of $63.1 \pm 5.3 \%$ for the $\mathrm{CH}_{4}$ content. The quality of the biogas produced under psychrophilic conditions demonstrated the good performance of the biogas digester. The positive control (crystalline cellulose) test demonstrated the ability of the inoculum to degrade a specific substrate and the quality of BMP assay. BMP from cellulose at $15^{\circ} \mathrm{C}$ was $0.40 \pm 0.01 \mathrm{Nm}^{3} \mathrm{CH}_{4} / \mathrm{kg}$ VS.

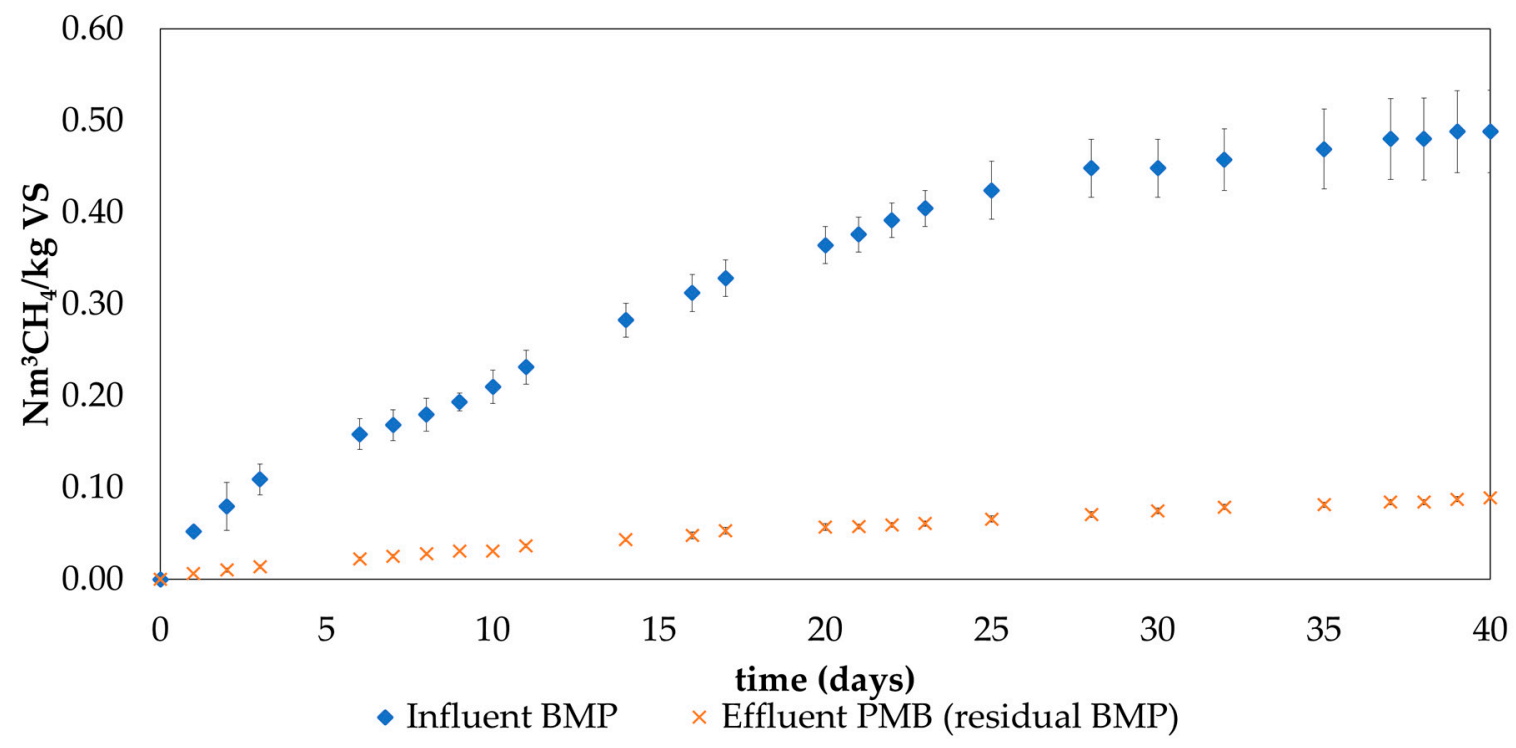

Figure 8. Influent (blue rhombus) and effluent (orange cruxes) biomethane potential kinetic.

Considering the difference of the methane potential between the affluent and effluent, the specific methane production (SMP) of the digester was estimated to be $0.40 \mathrm{Nm}^{3} \mathrm{CH}_{4} / \mathrm{kg}$ VS, which was higher than previously reported values, e.g., Lansing et al. [36] reported $0.29 \mathrm{~m}^{3} \mathrm{CH}_{4} / \mathrm{kg}$ VS. The hydraulic retention time of the digester, considering a mean inflow of $4.16 \mathrm{~m}^{3} / \mathrm{d}$ and a liquid volume of $103.1 \mathrm{~m}^{3}$, was around $25 \mathrm{~d}$. This retention time was very low for a $17.7^{\circ} \mathrm{C}$ slurry temperature, if compared with other psychrophilic swine manure fed digesters. Martí-Herrero et al. [19] reported the SMP of a 1.5-year old low cost tubular digester divided into two stages, obtaining $0.119 \mathrm{Nm}^{3} \mathrm{CH}_{4} / \mathrm{KgS} \mathrm{V}$ for $68.21 \mathrm{~d}$ and $0.093 \mathrm{Nm}^{3} \mathrm{CH}_{4} / \mathrm{Kg}$ VS for $34.11 \mathrm{~d}$, and $21.6^{\circ} \mathrm{C}$ of slurry temperature in both cases. So, the current digester, even with a short retention time, achieved a good SMP compared with similar digesters, despite working at higher temperatures. 
The methane production rate (MPR), considering that the mean OLR was $0.52 \mathrm{~kg} \mathrm{VS} / \mathrm{m}^{3}$ digester $\mathrm{d}$, was $0.21 \mathrm{Nm}_{3} \mathrm{CH}_{4} / \mathrm{m}^{3}$ digester $\mathrm{d}$, which was again higher that the values reported by Lansing et al. [36] and Marti-Herrero et al. [19] for low cost tubular digesters fed with swine manure.

Therefore, the digester showed a biogas yield that was higher than expected if compared with similar digesters. The main difference was that in our study, the digester had been working for 8 consecutive years (compared to 1.5 years in the study by Marti-Herrero et al. [19]). This long working period allowed an anaerobic digestion microorganism consortium to develop which was extremely well-adapted to local temperature, operation and influent properties. This phenomenon requires further research. The performance characterization of the digester, is shown in Table 2.

Table 2. Operational conditions, parameter measured and performance characterization of the full-scale low-cost tubular digester.

\begin{tabular}{|c|c|c|c|}
\hline Operational Conditions & Units & \multicolumn{2}{|c|}{ Value } \\
\hline Working years & years & \multicolumn{2}{|c|}{8} \\
\hline Volume & $\mathrm{m}^{3}$ & \multicolumn{2}{|c|}{103.1} \\
\hline Daily mean load & $\mathrm{m}^{3} / \mathrm{d}$ & \multicolumn{2}{|c|}{4.16} \\
\hline Mean slurry temperature & ${ }^{\circ} \mathrm{C}$ & \multicolumn{2}{|c|}{17.7} \\
\hline Mean ambient temperature & ${ }^{\circ} \mathrm{C}$ & \multicolumn{2}{|c|}{16.6} \\
\hline ORL & $\mathrm{kg} \mathrm{VS} / \mathrm{m}^{3}{ }_{\text {digester }} \mathrm{d}$ & \multicolumn{2}{|c|}{0.34 to 0.76 (mean 0.52 ) } \\
\hline HRT & $\mathrm{d}$ & \multicolumn{2}{|c|}{25} \\
\hline Parameters & Units & Influent value & Effluent value \\
\hline COD & $\mathrm{gCOD} / \mathrm{L}$ & $9.94 \pm 3.25$ & $3.31 \pm 1.20$ \\
\hline VS & $\mathrm{gVS} / \mathrm{kg}$ & $12.74 \pm 3.52$ & $2.86 \pm 1.2$ \\
\hline $\mathrm{pH}$ & - & $6.15 \pm 0.77$ & $7.6 \pm 0.3$ \\
\hline tVFA & $\mathrm{g} \mathrm{CODVFA}_{\mathrm{VA}} / \mathrm{L}$ & $2.9 \pm 1.3$ & $0.3 \pm 0.08$ \\
\hline $\mathrm{TA}$ & $\mathrm{g} \mathrm{CaCO}_{3} / \mathrm{L}$ & $3.72 \pm 1.3$ & $1.95 \pm 0.25$ \\
\hline Ammonium & $\mathrm{g} \mathrm{NH} 4-\mathrm{N} / \mathrm{L}$ & $0.34 \pm 0.05$ & $0.28 \pm 0.03$ \\
\hline $\mathrm{BMP}$ & $\mathrm{Nm}^{3} \mathrm{CH}_{4} / \mathrm{kgVS}$ & $0.46 \pm 0.017$ & $0.13 \pm 0.06$ \\
\hline Coliforms & $\times 10^{6} \mathrm{CFU} / \mathrm{mL}$ & 3.99 & 3.57 \\
\hline \multicolumn{4}{|c|}{ Performance characterization } \\
\hline $\mathrm{CH}_{4}$ & $\%$ & \multicolumn{2}{|c|}{$63.1 \pm 5.3$} \\
\hline SMP & $\mathrm{Nm}^{3} \mathrm{CH}_{4} / \mathrm{kg} \mathrm{VS}$ & \multicolumn{2}{|c|}{0.40} \\
\hline MPR & $\mathrm{Nm}^{3} \mathrm{CH}_{4} / \mathrm{m}^{3}$ digester $\mathrm{d}$ & \multicolumn{2}{|c|}{0.21} \\
\hline COD reduction & $\%$ & \multicolumn{2}{|c|}{$66.7 \%$} \\
\hline VS reduction & $\%$ & \multicolumn{2}{|c|}{$77.6 \%$} \\
\hline Coliforms reduction & $\%$ & \multicolumn{2}{|c|}{$10.5 \%$} \\
\hline
\end{tabular}

\subsection{Microbiological Analysis}

At low temperatures, methane formation occurred mainly by the acetoclastic route. An acetoclastic methanogenic activity test may be used to delineate the operating conditions for anaerobic systems and a parameter to assess the system performance by giving a better sense of the system and its stability [27]. In the present study, effluent acetoclastic SMA (0.06 $\mathrm{g} \mathrm{COD} \mathrm{CH}_{4} / \mathrm{gVS}$ d) was considerably higher than in the influent $(0.01 \mathrm{~g}$ COD $\mathrm{CH}_{4} / \mathrm{g}$ VS d). The SMA for a three-year operating cattle manure digester was $0.01 \mathrm{~g}$ COD $\mathrm{CH}_{4} / \mathrm{gVS}$ and $0.04 \mathrm{~g} \mathrm{COD} \mathrm{CH}_{4} / \mathrm{g} \mathrm{VS} \mathrm{d}$, for influent and effluent, respectively (previous study, data not shown). This behavior was because the tubular digester design highlighted the separation phases in the axial direction: acid phase (at the beginning of the digester) and methane phase (in the final digester). Therefore, the highest number of archaea was at the end of the digester, and consequently, the SMA increased [40]. Moreover, substrate type and temperature were the primary factors influencing microbial activity. From the effluent SMA, it was possible to infer that the bacteria and archaea had adapted to low temperatures after 8 years. 
Microbial relative abundances data at the family taxonomic level reflected a remarkable differentiation between inlet and outlet samples (Figure 9).
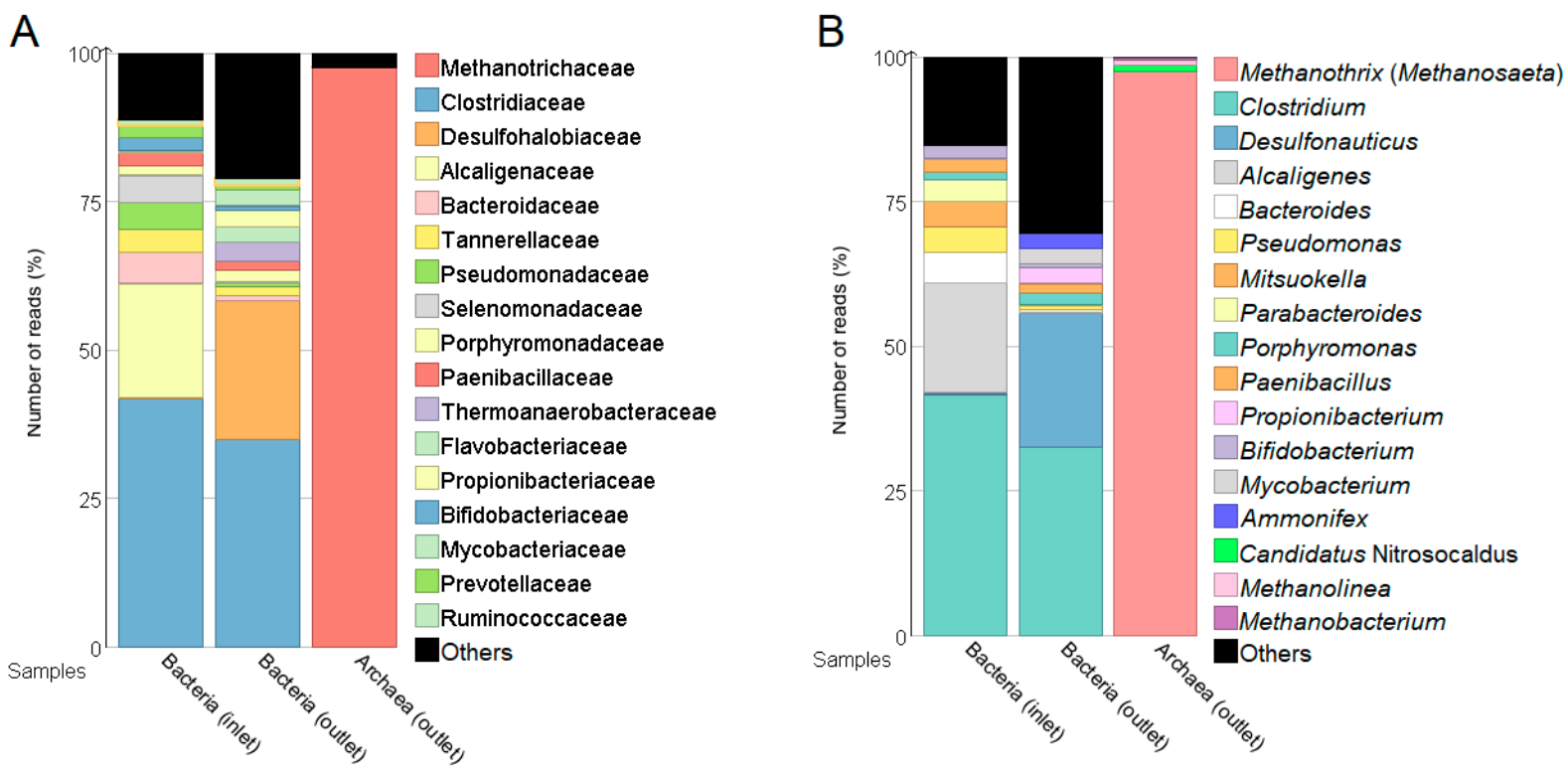

Figure 9. Abundance of bacterial and archaeal taxa at (A) family, and (B) genus taxonomic level in inlet and outlet samples.

The bacterial populations were dominated by hydrolytic and fermentative organisms which were capable of metabolizing the compounds present in the environment of the digester, such as members of Clostridiaceae and the Clostridium genus, whose proportions remained relatively stable throughout the digestion process and showed only a slight decrease in community composition in the outlet sample. Anaerobic and fermentative bacteria typically found in anaerobic digestion systems, such as members of Bacteroidaceae, Propionibacteriaceae, Syntrophaceae, Anaerolineaceae, or Geobacteraeace families, were present in the outlet sample. Propionibacteriaceae members are able to carry out fermentation of sugars to propionic acid [46], present in high quantities in the digester. Syntrophaceae can have a fermentative metabolism or grow in the exclusive presence of $\mathrm{H}_{2}$ (specifically, genus Syntrophus is able to degrade fatty acid chains in a symbiotic relationship with methanogens) [47], whereas Anaerolineaceae can use carbohydrates and Geobacteraceae can oxidize acetic acid and mainly use organic acids and alcohols [48]. Anaerobic conditions also produced a marked increase of Desulfonauticus (Desulfohalobiaceae), Firmicutes, and Actinobacteria taxa in outlet samples in comparison to inlet samples. In contrast, the anaerobic conditions created an unfavorable selective pressure for those organisms that were fundamentally aerobic, and resulted in appreciable shifts of most of the remaining bacterial populations. For example, the Alcaligenes (Alcaligenaceae) genus was not detectable in the outlet sample. The proportions of other bacterial genera such as Bacterioides (Bacteroidaceae), Parabacteroides (Porphyromonadaceae), Pseudomonas (Pseudomonadaceae) and Mitsukoella (Veillonellaceae), among others, drastically reduced between inlet and outlet samples, suggesting a poor adaptation and a displacement in favor of other microorganisms.

Regarding archaeal populations, even though the cell abundance in the inlet sample was not high enough to obtain a 16S rRNA amplicon sequencing dataset, the archaeal populations in the outlet sample were dominated almost exclusively by the methanogenic genus Methanothrix (formerly Methanosaeta) [49], followed by Methanobacterium and Methanolinea in lesser proportions. Methanothrix species are obligately anaerobic, using acetic acid as their sole source of energy; its metabolism results in the production of $\mathrm{CH}_{4}$ and $\mathrm{CO}_{2}$ [50]. The above suggests that the anaerobic process is ongoing, and that these archaeal populations are responsible for the methane found in the outlet sample. Overall, 
the anaerobic conditions in the reactor produced unfavorable shifts in the composition of the microbial community, favoring taxa which are typically found in anaerobic digestion systems, such as the hydrolytic populations of Clostridiaceae, the fermentative populations of Bacteroidaceae, Propionibacteriaceae, Syntrophaceae, Anaerobilneacea, or Geobacteraeace, and the methanogenic populations of Methanotrichaceae, Methanoregulaceae and Nitrosocaldeaceae families.

qPCR data for bacteria and archaea from the inlet and outlet reflected a clear differentiation between samples (Figure 10).

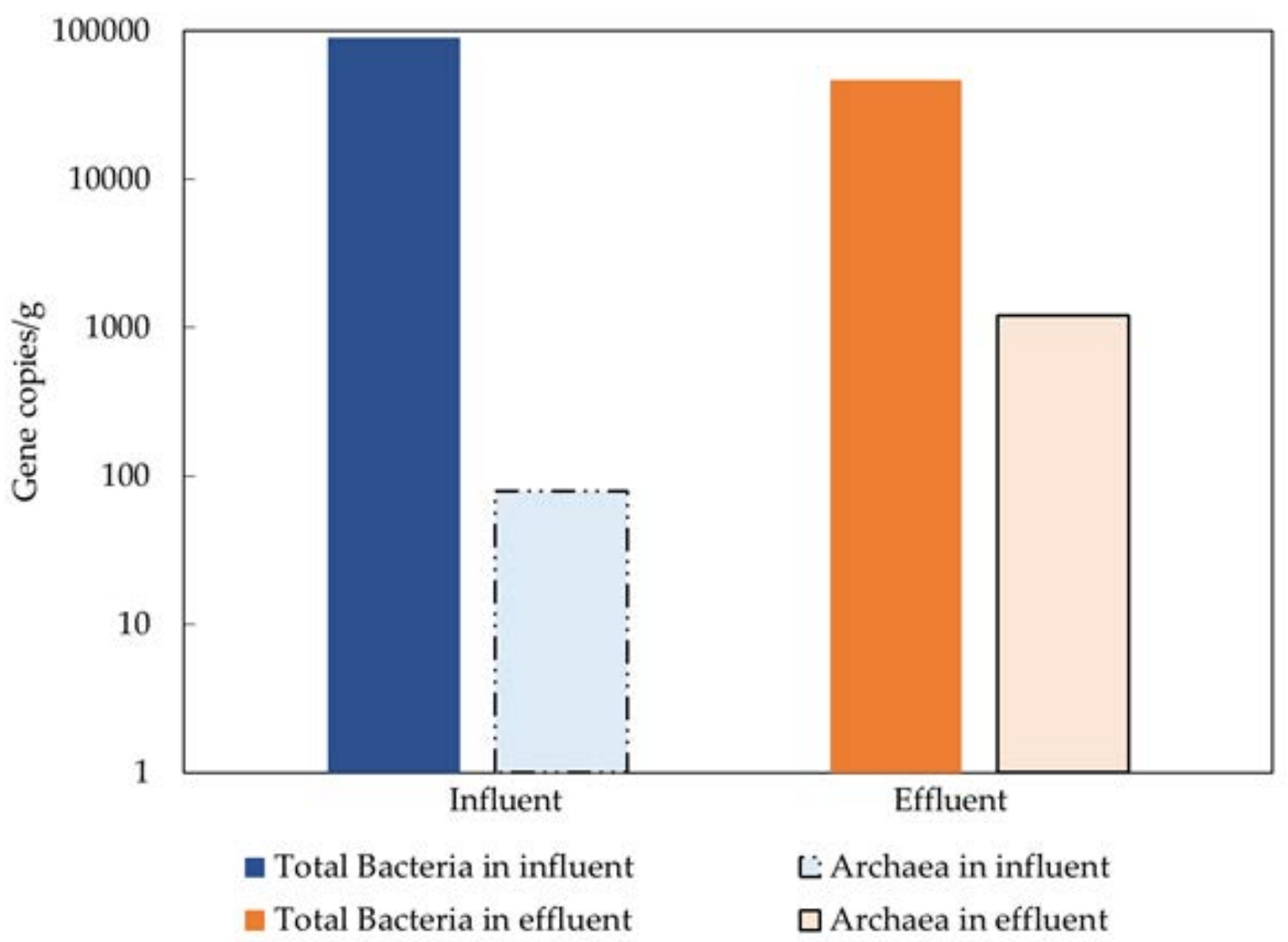

Figure 10. qPCR results for bacteria and archaea from inlet and outlet samples.

The qPCR results seem to indicate that the process provided a selective environment which was favorable to archaea communities with an approximate 15-fold increase from the inlet, which was consistent with the development of a community specialized in methanogenesis. In contrast, the bacteria communities experienced a decrease of approximately $48 \%$. The low values of archaea DNA obtained from the input sample made it impossible to study their relative abundance.

\subsection{Pathogen Reduction}

The digestate produced in the biodigester was characterized to evaluate its $\mathrm{mi}$ crobiological and nutritional quality. In the affluent and effluent, a concentration of $3.99 \times 10^{6} \mathrm{CFU} / \mathrm{mL}$ and $3.57 \times 10^{6} \mathrm{CFU} / \mathrm{mL}$, respectively, of total coliforms was quantified. This indicated that the digestate was Class B and needed to be stabilized before being dumped into arable soil [51]. Pathogen reduction was $0.42 \times 10^{6} \mathrm{CFU} / \mathrm{mL}$; this removal was low compared to that achieved for mesophilic anaerobic processes [52]. This is because the low temperatures did not affect the pathogenic microorganisms. 


\section{Conclusions}

A tubular plastic digester working under psychrophilic conditions for 8 years showed better biogas production than expected when compared with other low-cost tubular digesters A greenhouse over the tubular digester is not enough to heat the digester; therefore, other factors (the color of the reactor and the insulation used in the trench) should be considered for a passive solar heating design. The digester worked properly for organic matter removal and COD reduction, but the effluent still had a large number of coliforms in need of post-treatment (Class B). Performance during the long-term operation of these systems in psychrophilic conditions tends to improve, an aspect not previously considered nor evaluated. The digester had a very short retention time ( 25 days) for a psychrophilic condition $\left(17.7^{\circ} \mathrm{C}\right)$, indicating that the high methane production $\left(0.40 \mathrm{Nm}^{3} \mathrm{CH}_{4} / \mathrm{kg}\right.$ VS) could be related to the acclimatization and adaptation of the microorganism consortium to the local psychrophilic conditions. A microbiological analysis showed a diverse population adapted to anaerobic digestion conditions, with an increase of methanogenic archaea and a diminution of bacteria populations, resulting in a population that was specialized in hydrolytic and fermentative processes.

Author Contributions: J.J.-E., L.d.P.C., H.E.H., A.M. and J.M.-H. developed the conceptualization, wrote the manuscript; C.G. and A.P. conducted the experiments. G.P. and G.Z. realized the microbiological analysis. All authors have read and agreed to the published version of the manuscript.

Funding: This research was funded by Universidad Industrial de Santander. Colombia.

Institutional Review Board Statement: Not applicable.

Informed Consent Statement: Not applicable.

Data Availability Statement: The data presented in this study are available on request from the corresponding author.

Acknowledgments: The authors are grateful to Granja Porcícola La Loma, located in Güicán town, Colombia.

Conflicts of Interest: The authors declare no conflict of interest.

\section{References}

1. Martí-Herrero, J.; Alvarez, R.; Rojas, M.; Aliaga, L.; Céspedes, R.; Carbonell, J. Improvement through low cost biofilm carrier in anaerobic tubular digestion in cold climate regions. Bioresour. Technol. 2014, 167, 87-93. [CrossRef]

2. Garfí, M.; Martí-Herrero, J.; Garwood, A.; Ferrer, I. Household anaerobic digesters for biogas production in Latin America: A review. Renew. Sustain. Energy Rev. 2016, 60, 599-614. [CrossRef]

3. Sambusiti, C.; Monlau, F.; Ficara, E.; Musatti, A.; Rollini, M.; Barakat, A.; Malpei, F. Comparison of various post-treatments for recovering methane from agricultural digestate. Fuel Process. Technol. 2015, 137, 359-365. [CrossRef]

4. Guilayn, F.; Jimenez, J.; Martel, J.-L.; Rouez, M.; Crest, M.; Patureau, D. First fertilizing-value typology of digestates: A decision-making tool for regulation. Waste Manag. 2019, 86, 67-79. [CrossRef]

5. Castro, L.; Escalante, H.; Jaimes-Estévez, J.; Díaz, L.; Vecino, K.; Rojas, G.; Mantilla, L. Low cost digester monitoring under realistic conditions: Rural use of biogas and digestate quality. Bioresour. Technol. 2017, 239, 311-317. [CrossRef] [PubMed]

6. Dev, S.; Saha, S.; Kurade, M.B.; Salama, E.-S.; El-Dalatony, M.M.; Ha, G.-S.; Chang, S.W.; Jeon, B.-H. Perspective on anaerobic digestion for biomethanation in cold environments. Renew. Sustain. Energy Rev. 2019, 103, 85-95. [CrossRef]

7. Dohoo, C.; Guernsey, J.R.; Gibson, M.D.; Van Leeuwen, J. Impact of biogas digesters on cookhouse volatile organic compound exposure for rural Kenyan farmwomen. J. Expo. Sci. Environ. Epidemiol. 2013, 25, 167-174. [CrossRef] [PubMed]

8. Anderson, G.K.; Yang, G. Determination of bicarbonate and total volatile acid concentration in anaerobic digesters using a simple titration. Water Environ. Res. 1992, 64, 53-59. [CrossRef]

9. Raposo, F.; Borja, R.; Cacho, J.; Mumme, J.; Orupõld, K.; Esteves, S.; Noguerol-Arias, J.; Picard, S.; Nielfa, A.; Scherer, P.; et al. First international comparative study of volatile fatty acids in aqueous samples by chromatographic techniques: Evaluating sources of error. TrAC Trends Anal. Chem. 2013, 51, 127-143. [CrossRef]

10. Garfi, M.; Ferrer-Martí, L.; Pérez, I.; Flotats, X.; Ferrer, I. Codigestion of cow and guinea pig manure in low-cost tubular digesters at high altitude. Ecol. Eng. 2011, 37, 2066-2070. [CrossRef]

11. Fotidis, I.A.; Laranjeiro, T.F.V.C.; Angelidaki, I. Alternative co-digestion scenarios for efficient fixed-dome reactor biomethanation processes. J. Clean. Prod. 2016, 127, 610-617. [CrossRef]

12. Holliger, C.; Alves, M.; Andrade, D.; Angelidaki, I.; Astals, S.; Baier, U.; Bougrier, C.; Buffière, P.; Carballa, M.; De Wilde, V.; et al. Towards a standardization of biomethane potential tests. Water Sci. Technol. 2016, 74, 2515-2522. [CrossRef] [PubMed] 
13. Martí-Herrero, J.; Flores, T.; Alvarez, R.; Pérez, D. How to report biogas production when monitoring small-scale digesters in field. Biomass- Bioenergy 2016, 84, 31-36. [CrossRef]

14. Perrigault, T.; Weatherford, V.; Martí-Herrero, J.; Poggio, D. Towards thermal design optimization of tubular digesters in cold climates: A heat transfer model. Bioresour. Technol. 2012, 124, 259-268. [CrossRef] [PubMed]

15. Feller, G. Cryosphere and Psychrophiles: Insights into a Cold Origin of Life? Life 2017, 7, 25. [CrossRef] [PubMed]

16. Martí-Herrero, J.; Alvarez, R.; Flores, T. Evaluation of the low technology tubular digesters in the production of biogas from slaughterhouse wastewater treatment. J. Clean. Prod. 2018, 199, 633-642. [CrossRef]

17. Park, J.-H.; Park, J.-H.; Lee, S.-H.; Jung, S.P.; Kim, S.-H. Enhancing anaerobic digestion for rural wastewater treatment with granular activated carbon (GAC) supplementation. Bioresour. Technol. 2020, 315, 123890. [CrossRef]

18. Lansing, S.; Víquez, J.; Martínez, H.; Botero, R.; Martin, J. Quantifying electricity generation and waste transformations in a low-cost, plug-flow anaerobic digestion system. Ecol. Eng. 2008, 34, 332-348. [CrossRef]

19. Martí-Herrero, J.; Ceron, M.; Garcia, R.; Pracejus, L.; Alvarez, R.; Cipriano, X. The influence of users' behavior on biogas production from low cost tubular digesters: A technical and socio-cultural field analysis. Energy Sustain. Dev. 2015, 27, 73-83. [CrossRef]

20. Garfí, M.; Ferrer-Martí, L.; Velo, E.; Ferrer, I. Evaluating benefits of low-cost household digesters for rural Andean communities. Renew. Sustain. Energy Rev. 2012, 16, 575-581. [CrossRef]

21. Gulhane, M.; Khardenavis, A.; Karia, S.; Pandit, P.; Kanade, G.S.; Lokhande, S.; Vaidya, A.N.; Purohit, H.J. Biomethanation of vegetable market waste in an anaerobic baffled reactor: Effect of effluent recirculation and carbon mass balance analysis. Bioresour. Technol. 2016, 215, 100-109. [CrossRef] [PubMed]

22. Martí-Herrero, J.; Soria-Castellón, G.; Diaz-De-Basurto, A.; Alvarez, R.; Chemisana, D. Biogas from a full scale digester operated in psychrophilic conditions and fed only with fruit and vegetable waste. Renew. Energy 2019, 133, 676-684. [CrossRef]

23. McAteer, P.G.; Trego, A.C.; Thorn, C.; Mahony, T.; Abram, F.; O’Flaherty, V. Reactor configuration influences microbial community structure during high-rate, low-temperature anaerobic treatment of dairy wastewater. Bioresour. Technol. 2020, 307, 123221. [CrossRef] [PubMed]

24. IDEAM. GLACIARES. 2020. Available online: http://www.ideam.gov.co/web/otros-ecosistemas/investigacion-ypublicaciones?p_p_id=31_INSTANCE_x512d9DnqhhZ\&p_p_lifecycle=0\&p_p_state=normal\&p_p_mode=view\&p_p_col_ id=column-1\&p_p_col_pos=1\&p_p_col_count=3\&_31_INSTANCE_x512d9DnqhhZ_struts_action=\%2Fimage_g (accessed on 29 December 2020).

25. APHA. Standard Methods for the Examination of Water \& Wastewater; Eaton, D.A., Franson, H.M.A., Eds.; American Public Health Association (APHA): Leamington, ON, Canada, 2005.

26. Purser, B.J.; Thai, S.-M.; Fritz, T.; Esteves, S.; Dinsdale, R.; Guwy, A. An improved titration model reducing over estimation of total volatile fatty acids in anaerobic digestion of energy crop, animal slurry and food waste. Water Res. 2014, 61, 162-170. [CrossRef]

27. Astals, S.; Batstone, D.; Tait, S.; Jensen, P. Development and validation of a rapid test for anaerobic inhibition and toxicity. Water Res. 2015, 81, 208-215. [CrossRef]

28. Callaway, T.R.; Dowd, S.E.; Wolcott, R.D.; Sun, Y.; McReynolds, J.; Edrington, T.; Byrd, J.A.; Anderson, R.C.; Krueger, N.; Nisbet, D.J. Evaluation of the bacterial diversity in cecal contents of laying hens fed various molting diets by using bacterial tag-encoded FLX amplicon pyrosequencing. Poult. Sci. 2009, 88, 298-302. [CrossRef]

29. Takai, K.; Horikoshi, K. Rapid Detection and Quantification of Members of the Archaeal Community by Quantitative PCR Using Fluorogenic Probes. Appl. Environ. Microbiol. 2000, 66, 5066-5072. [CrossRef]

30. Sotres, A.; Tey, L.; Bonmatí, A.; Viñas, M. Microbial community dynamics in continuous microbial fuel cells fed with synthetic wastewater and pig slurry. Bioelectrochemistry 2016, 111, 70-82. [CrossRef]

31. San-Martín, M.I.; Sotres, A.; Alonso, R.M.; Díaz-Marcos, J.; Morán, A.; Escapa, A. Assessing anodic microbial populations and membrane ageing in a pilot microbial electrolysis cell. Int. J. Hydrogen Energy 2019, 44, 17304-17315. [CrossRef]

32. Martí-Herrero, J.; Chipana, M.; Cuevas, C.; Paco, G.; Serrano, V.; Zymla, B.; Heising, K.; Sologuren, J.; Gamarra, A. Low cost tubular digesters as appropriate technology for widespread application: Results and lessons learned from Bolivia. Renew. Energy 2014, 71, 156-165. [CrossRef]

33. Castro-Molano, L.D.P.; Parrales-Ramírez, Y.A.; Escalante-Hernández, H. Co-digestión anaerobia de estiércoles bovino, porcino y equino como alternativa para mejorar el potencial energético en digestores domésticos. Rev. ION 2019, 32, 29-39. [CrossRef]

34. Yao, Y.; Huang, G.; An, C.; Chen, X.; Zhang, P.; Xin, X.; Shen, J.; Agnew, J. Anaerobic digestion of livestock manure in cold regions: Technological advancements and global impacts. Renew. Sustain. Energy Rev. 2020, 119, 109494. [CrossRef]

35. Pedraza, G.; Chará, J.; Conde, N.; Giraldo, S.; Giraldo, L. Evaluation of polyethylene and PVC tubular biodigesters in the treatment of swine wastewater. Livest. Res. Rural Dev. 2002, 14. Available online: http://www.lrrd.org/lrrd14/1/Pedr141.htm (accessed on 29 December 2020).

36. Lansing, S.; Martin, J.F.; Botero, R.B.; Da Silva, T.N.; Da Silva, E.D. Methane production in low-cost, unheated, plug-flow digesters treating swine manure and used cooking grease. Bioresour. Technol. 2010, 101, 4362-4370. [CrossRef]

37. Gerardi, M.H. Temperature. In The Microbiology of Anaerobic Digesters; John Wiley \& Sons, Inc.: Hoboken, NJ, USA, 2003; pp. 89-92.

38. Nozhevnikova, A.N.; Rebak, S.; Kotsyurbenko, O.R.; Parshina, S.; Holliger, C.; Lettinga, G. Anaerobic production and degradation of volatile fatty acids in low temperature environments. Water Sci. Technol. 2000, 41, 39-46. [CrossRef] 
39. Hill, D.T.; Cobb, S.A.; Bolte, J.P. Using Volatile Fatty Acid Relationships to Predict Anaerobic Digester Failure. Trans. ASAE 1987, 30, 0496-0501. [CrossRef]

40. Jaimes-Estévez, J.; Castro, L.; Escalante, H.; Carrillo, D.; Portillo, S.; Sotres, A.; Morán, A. Cheese whey co-digestion treatment in a tubular system: Microbiological behaviour along the axial axis. Biomass Convers Biorefin. 2020. [CrossRef]

41. Yenigun, O.; Demirel, B. Ammonia inhibition in anaerobic digestion: A review. Process. Biochem. 2013, 48, 901-911. [CrossRef]

42. Hobson, P.; Shaw, B. Inhibition of methane production by Methanobacterium formicicum. Water Res. 1976, 10, 849-852. [CrossRef]

43. Massé, D.I.; Rajagopal, R.; Singh, G. Technical and operational feasibility of psychrophilic anaerobic digestion biotechnology for processing ammonia-rich waste. Appl. Energy 2014, 120, 49-55. [CrossRef]

44. Wei, S.; Guo, Y. Comparative study of reactor performance and microbial community in psychrophilic and mesophilic biogas digesters under solid state condition. J. Biosci. Bioeng. 2018, 125, 543-551. [CrossRef]

45. Kafle, G.K.; Chen, L. Comparison on batch anaerobic digestion of five different livestock manures and prediction of biochemical methane potential (BMP) using different statistical models. Waste Manag. 2016, 48, 492-502. [CrossRef] [PubMed]

46. Stackebrandt, E.; Cummins, C.S.; Johnson, J.L. Family Propionibacteriaceae: The Genus Propionibacterium. Prokaryotes 2006, 2006, 400-418. [CrossRef]

47. Kuever, J. The Family Syntrophaceae. In The Prokaryotes: Deltaproteobacteria and Epsilonproteobacteria; Springer: Heidelberg, Germany, 2014; Volume 9783642390, pp. 1-413. [CrossRef]

48. Zhuang, L.; Tang, Z.; Yu, Z.; Li, J.; Tang, J. Methanogenic Activity and Microbial Community Structure in Response to Different Mineralization Pathways of Ferrihydrite in Paddy Soil. Front. Earth Sci. 2019, 7, 1-11. [CrossRef]

49. The Prokaryotes. The Prokaryotes; Springer Science and Business Media LLC: Berlin/Heidelberg, Germany, 2014; Volume 2014, pp. 298-305.

50. McIlroy, S.J.; Kirkegaard, R.H.; Dueholm, M.S.; Fernando, E.; Karst, S.M.; Albertsen, M.; Nielsen, P.H. Culture-Independent Analyses Reveal Novel Anaerolineaceae as Abundant Primary Fermenters in Anaerobic Digesters Treating Waste Activated Sludge. Front. Microbiol. 2017, 8, 1134. [CrossRef]

51. USEPA. Enviromental Regulations and Technology. Control of Pathogens and Vector Attraction in Sewage Sludge; United States Environment Protection Agency: Washington, DC, USA, 2003.

52. Ju, F.; Liping, M.; Ma, L.; Wang, Y.; Huang, D.; Zhang, T. Antibiotic resistance genes and human bacterial pathogens: Cooccurrence, removal, and enrichment in municipal sewage sludge digesters. Water Res. 2016, 91, 1-10. [CrossRef] 